\title{
Not Like Everybody Else. Essays in Honor of Kees Mandemakers
}

\section{By Jan Kok, Hilde Bras and Richard L. Zijdeman}

To cite this article: Kok, J., Bras, H. \& Zijdeman, R. L. (2021). Not Like Everybody Else. Essays in Honor of Kees Mandemakers. Historical Life Course Studies, 10, 01-04. https://doi.org/10.51964/hlcs9556

\section{HISTORICAL LIFE COURSE STUDIES}

Not Like Everybody Else.

Essays in Honor of Kees Mandemakers

VOLUME 10, SPECIAL ISSUE 3

2021

GUEST EDITORS

Hilde Bras

Jan Kok

Richard L. Zijdeman 


\section{HISTORICAL LIFE COURSE STUDIES}

Historical Life Course Studies is the electronic journal of the European Historical Population Samples Network (EHPSNet). The journal is the primary publishing outlet for research involved in the conversion of existing European and nonEuropean large historical demographic databases into a common format, the Intermediate Data Structure, and for studies based on these databases. The journal publishes both methodological and substantive research articles.

\section{Methodological Articles}

This section includes methodological articles that describe all forms of data handling involving large historical databases, including extensive descriptions of new or existing databases, syntax, algorithms and extraction programs. Authors are encouraged to share their syntaxes, applications and other forms of software presented in their article, if pertinent, on the openjournals website.

\section{Research articles}

This section includes substantive articles reporting the results of comparative longitudinal studies that are demographic and historical in nature, and that are based on micro-data from large historical databases.

Historical Life Course Studies is a no-fee double-blind, peer-reviewed open-access journal supported by the European Science Foundation (ESF, http://www.esf.org), the Scientific Research Network of Historical Demography (FWO Flanders, http://www.historicaldemography.be) and the International Institute of Social History in Amsterdam (IISH, http://socialhistory.org/). Manuscripts are reviewed by the editors, members of the editorial and scientific boards, and by external reviewers. All journal content is freely available on the internet at https://openjournals.nl/index.php/hlcs.

\section{Co-Editors-In-Chief:}

Paul Puschmann (Radboud University) \& Luciana Quaranta (Lund University)

hislives@kuleuven.be

The European Science Foundation (ESF) provides a platform for its Member Organisations to advance science and explore new directions for research at the European level. Established in 1974 as an independent non-governmental organisation, the ESF currently serves 78 Member Organisations across 30 countries. EHPS-Net is an ESF Research Networking Programme.

The European Historical Population Samples Network (EHPS-net) brings together scholars to create a common format for databases containing non-aggregated information on persons, families and households. The aim is to form an integrated and joint interface between many European and non-European databases to stimulate comparative research on the micro-level.

Visit: http://www.ehps-net.eu.
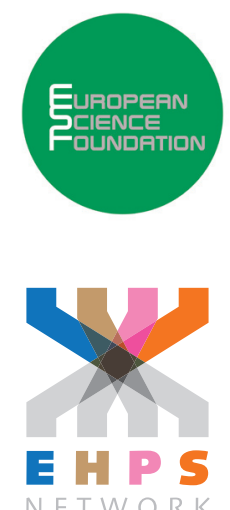


\title{
Not Like Everybody Else
}

\section{Essays in Honor of Kees Mandemakers}

\author{
Jan Kok
}

Radboud University Nijmegen

Hilde Bras

University of Groningen

Richard L. Zijdeman

International Institute of Social History, Amsterdam \& University of Stirling

\section{ABSTRACT}

This collection of essays pays tribute to Kees Mandemaker's great contribution to the data infrastructure of social science history, in the Netherlands and elsewhere. Several essays discuss (the future of) historical databases. Yet other provide examples of research on topics covering important life course transitions. All demonstrate the scale, scope and variation of research based on well-constructed databases.

Keywords: Historical databases, Social science history, Record linkage, Retirement, Life course

e-ISSN: $\quad 2352-6343$

DOI article: $\quad$ https://doi.org/10.51964/hlcs9556

The article can be downloaded from here. 
A lifelong devotee of The Kinks, Kees Mandemakers is undoubtedly familiar with their song 'I'm not like everybody else' (1967). The rebellious spirit of the song must have resonated with Kees' own early revolt against the strictures of religion, as he fondly recounts his discussions with the church minister trying to teach him catechism. Although he can be quite headstrong, Kees is not the type to protest for the sake of protest, in fact, he turned out be a 'rebel with a cause'. He devoted his career to the cause of supporting social history in its broadest sense with state-of-the art databases. This required rebelliousness but most of all perseverance. For the past thirty-odd years, Kees soldiered on in the face of a growing disdain for quantitative history. He weathered periods with, at best, lukewarm institutional support for his enterprises and limited financial sponsoring. In other periods, he resisted exaggerated faith in innovate techniques in database construction.

The focus of Kees' professional attention was the reconstruction of Dutch life courses and families in order to create an infrastructure for social science history. First and foremost, this entailed building the Historical Sample of the Netherlands, which is flanked by dozens of side-projects. Since 1989, Kees devoted all his time and energy to create, disseminate, enrich and expand the HSN, which by 2020 had resulted in no less than 412 scientific publications and 802 lectures and presentations (Annual Report 2019).

HSN is not completed. Actually, it is not even intended to be completed and then stored away in some data archive. The more than 80,000 individual life courses in HSN will be enriched with further data on networks, income, education, as well as with the life courses of offspring, which will allow for audacious explorations in social science history. But even more ambitious than HSN is the LINKS project that Kees embarked on some fifteen years ago. This project implies the complete reconstitution of all Dutch families in the 19th and early 20th century by linking all public civil records. For several provinces, the task is already completed.

From the start, Kees has put his Dutch databases squarely in an international network of similar initiatives. These initiatives inspired him and, conversely, his experiences found their way in the form of advice and papers on 'best practices' to database builders abroad. A crucial step in strengthening international collaboration was the Intermediate Data Structure, an identical output format for all historical databases. To construct and promote this format, Kees and others founded the European Historical Population Samples Network as well as the open access journal Historical Life Course Studies.

We cannot do full justice here to Kees' advice and support for many projects in several countries, his own research activities, his professorship at the Erasmus University Rotterdam and so on. But our appreciation for his work, support and friendship is profound. We hope to express our appreciation in this collection of short essays, that all have a direct bearing on Kees' professional mission.

Obviously, the creation of research infrastructures plays a large role in this special issue. New quality standards and future prospects of historical databases in general are discussed in the essays by Lionel Kesztenbaum, Kris Inwood and Hamish Maxwell-Stewart, Lex Heerma van Voss and Jan Kok. Peter Doorn argues that, despite the attention for Big Data, we should not forget the richness of small datasets. Several essays argue for the extension of HSN, e.g. through linking with criminal records (Sanne Muurling and Evelien Walhout), by adding causes of death (Tim Riswick) or by linking with the military records of the Dutch East Indies (Ulbe Bosma). The latter also describes the efforts to create a Netherlands Indies counterpart of HSN. An 'HSN' of Suriname is already under construction and Cornelis van Galen, Björn Quanjer, Matthias RosenbaumFeldbrügge and Matthijs Kraijo report on the first explorations of this database. Gerrit Bloothooft demonstrates nominal record linkage techniques using the surname 'Mandemakers'. New ways of database creation are explored by Gunnar Thorvaldsen who shows the prospects of automated source transcription. Angélique Janssens shows the advances in the creation of an international coding system for historical causes of death. Finally, the progress and prospects of the Intermediate Data Structure are the topic of three contributions, respectively by George Alter, Luciana Quaranta, and Sam Jenkinson, Hideko Matsuo and Koen Matthijs.

The other essays have a more empirical character. We can introduce them here by the stages of the life course they deal with. Theo Engelen analyzes the seasonality of conception in the Netherlands and Taiwan. Luminiţa Dumănescu and loan Bolovan describe the changing position of midwives in 19th-century Transylvania. Hilde Sommerseth reports on how stillbirths were defined in Norway. Peter Ekamper and Frans van Poppel compare mothers who had multiple births with mothers who had singletons only. Fertility is also the subject of the essay by Hilde Bras. She analyzes reconstituted families in Zeeland using LINKS and argues 
that even a 'high fertility' region had couples very different demographic profiles. Niels van den Berg, Ingrid van Dijk and Rick Mourits demonstrate that fertility of daughters of older mothers is reduced.

Work and education are important domains of the life course, and have always had Kees Mandemakers warmest interest. Elise van Nederveen Meerkerk discusses schooling in the Netherlands and Java between 1800 and 1940, reflecting Kees' own interest in education. Björn Quanjer and Kristina Thompson take an un unusual approach as they explore the shifting relation between education and obesity with conscript records. Corinne Boter uses the marriage certificates of LINKS and shows how regional differences in industrialization rather than social norms affect women's labour force participation.

Migration trajectories are explored in the essay by Myron Gutmann who puts the famous Dust Bowl migration to California in perspective by tracing the provenance of migrants 1935-1940. Matthias RosenbaumFeldbrügge and Paul Puschmann warn users of LINKS not to mistake place of marriage with the place of residence as this would overestimate male migration.

Other studies are concerned with health. Rick Mourits, Ruben Schalk, Albert Meroño-Peñuela, Joe Raad, Auke Rijpma, Bram van den Hout and Richard Zijdeman chose a timely subject and trace 'hotbeds' of the Spanish flu. Lotta Vikström, Sören Edvinsson and Erling Häggström Lundevaller look at disability and causes of death in 19th-century Sweden. Finally, Sander Wennemers and Hilde Bras use HSN to study life expectancy in the province of Overijssel.

Three essays may have some bearing on Kees Mandemaker's own history and life course. Stemming from an Orthodox Protestant family more or less on the frontier between 'Rome and Reformation', he will enjoy Hans Knippenberg's essay on the rise of Pillarization ('Verzuiling'). Ineke Maas, Marco van Leeuwen and Antonie Knigge look at the recruitment of university professors in the past and note the closed character of this occupation. For Kees, we can safely say that he reached this position on his own merits. Finally, Anders Brändström and Glenn Sandström study recent developments in retirement.

Kees Mandemakers may have stopped 'running 'round' and appears to have 'settled down' comfortably in Utrecht city. But we hope that, intellectually, he will never settle down but will keep on giving advice, writing history, and exploring new venues. Like every individual, Kees' life course is part and parcel of general societal processes, which translate to the micro-level in class-, gender-, age- and cohort-specific ways. But we are more than the sum of the variables determining our life course trajectories. With regard to Kees: his steadfast devotion, energy, relentless enthusiasm, and singular capacities make him, at least to us, truly unique, or in other words: Not Like Everybody Else.

\section{WORKS INCLUDED IN THIS SPECIAL ISSUE}

Alter, G. (2021). Reflections on the Intermediate Data Structure (IDS). Historical Life Course Studies, 10, 71-75. doi: 10.51964/hlcs9570

Bloothooft, G. (2021). A Kees study on nominal record linkage. Historical Life Course Studies, 10, 53-58. doi: $10.51964 /$ hlcs9567

Bosma, U. (2021). The HSN and the Netherlands Indies: Challenge and promise. Historical Life Course Studies, 10, 41-45. doi: 10.51964/hlcs9565

Boter, C. (2021). The emergence of the Dutch housewife revised. How shifts in local labour market structures shaped Dutch unmarried women's labour force participation, 1812-1929. Historical Life Course Studies, 10, 130-134. doi: 10.51964/hlcs9581

Brändström, A., \& Sandström, G. (2021). Retirement, home care and the importance of gender. Historical Life Course Studies, 10, 172-179. doi: 10.51964/hlcs9589

Bras, H. (2021). Heterogeneity in 'high fertility' societies. Insights from compositional demography. Historical Life Course Studies, 10, 106-111. doi: 10.51964/hlcs9577

Doorn, P. (2021). Historical databases, big and small. Historical Life Course Studies, 10, 24-29. doi: $10.51964 /$ hlcs9562

Dumănescu, L., \& Bolovan, I. (2021). Medicalisation of birth in Transylvania in the second half of the 19th century. A subject to be investigated. Historical Life Course Studies, 10, 91-95. doi: 10.51964/hlcs9574 
Ekamper, P., \& van Poppel, F. (2021). Maternal life-histories of multiple birth mothers compared to singleton only mothers in 19th and early 20th century Netherlands. Historical Life Course Studies, 10, 101-105. doi: $10.51964 /$ hlcs9576

Engelen, T. (2021). The rhythm of conceptions. Seasonality of births in Taiwan and the Netherlands, 18001940. Historical Life Course Studies, 10, 86-90. doi: 10.51964/hlcs9573

Gutmann, M. P. (2021). Simple sources for complex problems. Where did Californians come from in 1940? Historical Life Course Studies, 10, 135-139. doi: 10.51964/hlcs9582

Heerma van Voss, L. (2021). Fair and tender data. The FAIRness of four databases with historical individual life course data tested. Historical Life Course Studies, 10, 13-18. doi: 10.51964/hlcs9559

Inwood, K., \& Maxwell-Stewart, H. (2021). Historical databases now and in the future. Historical Life Course Studies, 10, 09-12. doi: 10.51964/hlcs9558

Janssens, A. (2021). Constructing SHiP and an international historical coding system for causes of death. Historical Life Course Studies, 10, 64-70. doi: 10.51964/hlcs9569

Jenkinson, S., Matsuo, H., \& Matthijs, K. (2021). LONGPOP and IDS. Personal reflections on our collaboration with Kees Mandemakers. Historical Life Course Studies, 10, 81-85. doi: 10.51964/hlcs9572

Kesztenbaum, L. (2021). Strength in numbers. A short note on the past, present and future of large historical databases. Historical Life Course Studies, 10, 05-08. doi: 10.51964/hlcs9557

Knippenberg, H. (2021). 1853: How pope Pius IX stimulated pillarization in the Netherlands. Historical Life Course Studies, 10, 162-166. doi: 10.51964/hlcs9587

Kok, J. (2021). The life span of large historical databases. Historical Life Course Studies, 10, 19-23. doi: $10.51964 /$ hlcs9561

Kok, J., Bras, H., \& Zijdeman, R. L. (2021). Not like everybody else. Essays in honor of Kees Mandemakers. Historical Life Course Studies, 10, 01-04. doi: 10.51964/hlcs9556

Maas, I., van Leeuwen, M. H. D., \& Knigge A. (2021). Intergenerational and marriage mobility of university professors in the Netherlands during the 19th century. Historical Life Course Studies, 10, 167-171. doi: $10.51964 / \mathrm{hlcs} 9588$

Mourits, R. J., Schalk, R., Meroño-Peñuela, A., Raad, J., Rijpma, A., van den Hout, B., \& Zijdeman, R. L. (2021). Retracing hotbeds of the 1918-19 influenza pandemic. Spatial differences in seasonal excess mortality in the Netherlands. Historical Life Course Studies, 10, 145-150. doi: 10.51964/ hlcs9584

Muurling, S., \& Walhout, E. (2021). Criminal life courses in context. Historical Life Course Studies, 10, 30-33. doi: 10.51964/hlcs9563

Quanjer, B., \& Thompson, K. (2021). The roots of the obesity boom. The relationship between overweight and educational level among Dutch men, 1950-1979. Historical Life Course Studies, 10, 124-129. doi: $10.51964 /$ hlcs9580

Quaranta, L. (2021). Reflections on the use of the Intermediate Data Structure (IDS) in historical demographic research. Historical Life Course Studies, 10, 76-80. doi: 10.51964/hlcs9571

Riswick, T. (2021). Enriching the HSN with individual causes of death. A database for a life-course analysis of victims and survivors. Historical Life Course Studies, 10, 34-40. doi: 10.51964/hlcs9564

Rosenbaum-Feldbrügge, M., \& Puschmann, P. (2021). Measuring migration status based on the place of marriage overestimates the share of male migrants in historical populations. Evidence from Dutch marriage certificates. Historical Life Course Studies, 10, 140-144. doi: 10.51964/hlcs9583

Sommerseth, H. L. (2021). Born dead or alive? Revisiting the definition of stillbirths in Norway. Historical Life Course Studies, 10, 96-100. doi: 10.51964/hlcs9575

Thorvaldsen, G. (2021). Automating historical source transcription. Historical Life Course Studies, 10, 5963. doi: $10.51964 /$ hlcs9568

van den Berg, N., van Dijk, I. K., \& Mourits, R. J. (2021). Women born to older mothers have reduced fertility. Evidence from a natural fertility population. Historical Life Course Studies, 10, 112-118. doi: 10.51964/hlcs9578

van Galen, C. W., Quanjer, B., Rosenbaum-Feldbrügge, M., \& Kraijo, M. (2021). Endless digging and endless picking. Sex ratios and gendered labour in Surinamese plantations, 1830-1863. Historical Life Course Studies, 10, 46-52. doi: 10.51964/hlcs9566

van Nederveen Meerkerk, E. (2021). Grammar of difference. General education in the Netherlands and Java, 1800-1940. Historical Life Course Studies, 10, 119-123. doi: 10.51964/hlcs9579

Vikström, L., Edvinsson, S., \& Häggström Lundevaller, E. (2021). Disability, mortality and causes of death in a 19th-century Swedish population. Historical Life Course Studies, 10, 151-155. doi: 10.51964/ hlcs9585

Wennemers, S., \& Bras, H. (2021). Surviving in Overijssel. An analysis of life expectancy, 1812-1912. Historical Life Course Studies, 10, 156-161. doi: 10.51964/hlcs9586 